\title{
The Interaction Effect of Cadmium and Nitrogen on Populus yunnanensis
}

\author{
Tiantian Lin \\ College of Forestry, Sichuan Agricultural University, Yaan 625014, China \\ Xiaoqiong Zhu \& Fan Zhang \\ College of Landscape Architecture, Sichuan Agricultural University, Chengdu 610000, China \\ Xueqin Wan (Corresponding author) \\ College of Forestry, Sichuan Agricultural University, Yaan 625014, China \\ Tel: 86-138-8163-4583 E-mail: wanxueq@yahoo.com
}

$\begin{array}{lc}\text { Received: June 20, } 2011 \quad \text { Accepted: July 12, } 2011 \quad \text { Online Published: December 21, } 2011 \\ \text { doi:10.5539/jas.v4n2p125 } & \text { URL: http://dx.doi.org/10.5539/jas.v4n2p125 }\end{array}$

The research was supported by the Key Project of Crop Breeding of Sichuan Province (No.2006Y2GG-10) and the Open-End Fund of National Engineering Laboratory of Forest Tree Breeding of BeiJing Forestry University (No.FOP 2010-7)

\begin{abstract}
In this study, we used Populus yunnanensis, a native precious poplar species which is only distributed in southwestern China, as a model species to study its morphological, physiological and biochemical responses to the interaction of different concentrations of nitrogen and cadmium, discussing the interaction effect of cadmium and nitrogen on Populus yunnanensis. The treatments consisted of three cadmium levels $(0 \mathrm{mg} / \mathrm{kg}, 2 \mathrm{mg} / \mathrm{kg}$ and $4 \mathrm{mg} / \mathrm{kg})$ and three nitrogen levels $(0 \mathrm{mg} / \mathrm{kg}, 20 \mathrm{mg} / \mathrm{kg}$ and $40 \mathrm{mg} / \mathrm{kg})$. After 40 days treatment, the results indicated that at the same nitrogen level, cadmium treatment had significant effects on all measured indexes, including plants growth, chlorophyll concentration, malondialdehyde (MDA) concentration, antioxidant enzymes activities (SOD, POD, CAT and APX), free proline, soluble protein and non-protein thiol. In addition, Populus yunnanensis also showed a certain degree of resistance to cadmium stress. Meanwhile, study also showed there were significant difference among the three levels of nitrogen treatments and the higher nitrogen treatment showed more significant effect of alleviation on cadmium induced damage than that of lower nitrogen treatment in Populus yunnanensis.
\end{abstract}

Keywords: Nitrogen, Cadmium, Antioxidant enzymes, Free proline, Soluble protein, Non-protein thiol

\section{Introduction}

With the development of urbanization and industrialization, the contamination of heavy metals which are directly produced and released by human activities directly implicated in the generation of oxidative stress in the plants surrounding environment, which make ecological environment became unbalanced and deteriorated. Cadmium $(\mathrm{Cd})$ is one of the major industrial pollutants because its highly toxicity and migration which shows its phytotoxicity even at low doses (Chakravarty, 1992; Das, 1997). This metal is especially active in the soil so it can be absorbed and accumulated by plants, which may cause obviously damage to plants growth and development. When $\mathrm{Cd}$ is over accumulated by plants, it will influence plants physiology and biochemistry activity, such as photosynthesis, respiration, transpiration or even relative gene expression, then performed by plants appearance such as leaves chlorosis, growth inhibition and even plants death.

In addition, recently reports showed that after adding nitrogen to plants, the damage caused by Cd stress can be efficiently alleviated. Moreover, plants even present better growth than those of plantss which did not under stress. Some research indicate that adding appropriate nitrogen in nutrient solution can obviously enhance the development of root system and increase accumulation of Cd in Sedum alfredii Hance (Li, 2007). Further, under the same concentration of Cd stress, the biomass of Kandelia candel dramatically increased with the increasing 
nitrogen (Zhang, 2008). Refer to these different research, researchers agreed that adding nitrogen can evidently alleviate the damage from $\mathrm{Cd}$ stress, and this effect can be differential along with the different plants species as well as the different concentration of both Cd and nitrogen (Zhang, 2008; Hassan, 2005).

Populus yunnanensis is one of the most valuable and unique poplar species which is distributed in high elevation regions of low latitudes and occurring only in southwestern China. P. yunnanensis is horizontal distributed in middle and northern Yunnan province and southwestern Sichuan province, and vertical distributed in altitude 800-3200 m. P. yunnanensis is one of the fast-growing tree species which plays an important role in forestry production and environmental protection. It is famous for fast growth, ornamental value and high adaptability which is widely used as afforestation and timber tree species. However, with the development of industrialization in southwestern China, the soil suffers increasing heavy metals pollution which had detrimental influence upon the growth and development of $P$. yunnanensis in this region. In this study, we comprehensively investigated the morphological, physiological and biochemical responses of $P$. yunnanensis under the interaction of different concentrations of nitrogen and $\mathrm{Cd}$ treatment. Our aims were to test the detoxification effect of nitrogen to $\mathrm{Cd}$ stress in $P$. yunnanensis as well as to study the interaction effect of heavy metal and nutrient element on $P$. yunnanensis. Therefore, the differential influence of different concentrations of $\mathrm{Cd}$ and $\mathrm{N}$ treatments on $P$. yunnanensis including the growth of height and DBH (diameter at breast height), chlorophyll content, antioxidant enzymes activities and lipid peroxidation, free proline content were observed after 40 days' exposure to different concentrations of $\mathrm{N}$ and $\mathrm{Cd}$ treatments. Hoping the results of this study can provide us theoretical and practical experiences to the protection of $P$. yunnanensis as well as other naive plants suffered from heavy metals pollution, thus promoting the development of methodology of plants remediation.

\section{Materials and Methods}

\subsection{Plants material and treatments}

81 healthy cuttings with an average of 5 nodes and about $15 \mathrm{~cm}$ of height were sampled from 81 different trees from their natural habitat (Meigu, Sichuan province). All trees were collected from the same population shared similar conditions of water and soil nutrients. After sampled, these 81 cuttings were replantsed into 27 plastic pots $\left(3\right.$ cuttings per pot, each pot is $20 \mathrm{~cm}^{*} 20 \mathrm{~cm}^{*} 30 \mathrm{~cm}$, which contained $30 \mathrm{~kg}$ homogenized soil $(\mathrm{pH}=$ $7.0 \pm 0.12)$.). The cuttings were grown in a naturally lit greenhouse which provided shelter from rainfall at the Sichuan Agricultural University. Cuttings were watered with tap water every 2 days to maintain $100 \%$ field capacity. In this study there were 3 treatments of Cadmiun including control $(0 \mathrm{mg} / \mathrm{kg})$, low Cd $(2 \mathrm{mg} / \mathrm{kg})$ and high Cd $(4 \mathrm{mg} / \mathrm{kg})$ and the 3 treatments of nitrogen comprising control $(0 \mathrm{mg} / \mathrm{kg})$, low N $(20 \mathrm{mg} / \mathrm{kg})$ and high $\mathrm{N}(40 \mathrm{mg} / \mathrm{kg})$. So there were totally 9 treatments and for each treatment it was set up in triplicate to ensure the reproducibility of results. When the cuttings grew at 8 to 10 leaf stage $(2-3$ weeks old, $20 \mathrm{~cm}$ in height), they were subjected to the above 9 treatments and each 3 pots as one group which was treated by the same treatment. The treatments started on 20 April 2010, and the plantss were harvested on 1 June 2010. The height and DBH (diameter at breast height) of each cutting was measured before treatments, leaves samples (about $8 \mathrm{~mm}$ diameter) were cut with a scissor from the third pair of leaves (counting from the bottom of the plants) after harvested, and stored immediately at $-80^{\circ} \mathrm{C}$ for later analysis.

\subsection{Measurement of chlorophyll content}

Leaf samples were taken from the third leaf counted from the top of plant right after harvested and used for determinations. After extraction with $80 \%$ acetone for 48 hours, the absorbance of Chlorophyll was measured by spectrophotometer at 645 and $663 \mathrm{~nm}$, according to Lichtenthaler (1987).

\subsection{Measurements and assays of antioxidant enzymes activities}

For SOD, CAT and POD extraction, leaf samples ( $0.5 \mathrm{~g}$ fresh leaves) were ground in liquid nitrogen and extracted with $50 \mathrm{mM}$ potassium phosphate buffer $(\mathrm{pH} 7.8)$ which contained $0.5 \mathrm{mM}$ EDTA with pre-chilled pestle and mortar. Each homogenate was transferred to centrifuge tubes and was centrifuged at $15000 \mathrm{~g}, 4^{\circ} \mathrm{C}$ for $15 \mathrm{~min}$. The supernatant was used for enzyme activity assay. For APX extraction, leaf samples $(0.5 \mathrm{~g})$ were homogenized in $50 \mathrm{mM}$ ice cold potassium phosphate buffer ( $\mathrm{pH} 7.5$ ) which contained $0.5 \mathrm{mM}$ EDTA, $2 \mathrm{mM}$ ascorbate (AsA) and 5\% poly vinyl pyrrolidin (PVP) with pre-chilled pestle and mortar. Other stages were similar to extraction of other enzymes (Esfandiari et al., 2007). All operations were performed at $0-4{ }^{\circ} \mathrm{C}$. SOD activity was estimated according to Sairam (2002), CAT activity was measured according to Aebi (1984) and the activity of POD were assayed according to the method of Guo et al. (2004) by monitoring the rate of guaiacol oxidation at $470 \mathrm{~nm}$. In addition, APX activity was measured according to Yoshimura (2000) by monitoring the rate of ascorbate oxidation at $290 \mathrm{~nm}$. A unit of antioxidant enzymes activities was expressed as the change in absorbance per minute and specific activities as enzyme units per $\mathrm{g}$ of fresh weight (FW). 


\subsection{Measurement of lipid peroxidation}

The level of lipid peroxidation was expressed by malondialdehyde (MDA) concentration which was measured by colorimetric method according to Stewart and Bewley (1980). $0.5 \mathrm{~g}$ of leaf samples were homogenized in 6 $\mathrm{ml}$ of $50 \mathrm{mM}$ potassium phosphate buffer $(\mathrm{pH} 7.8)$. To each $1 \mathrm{ml}$ aliquot of the supernatant, $2 \mathrm{ml}$ of $0.6 \%$ thiobarbituric acid (TBA) in $10 \%$ TCA was added. The mixtures were incubated at $95^{\circ} \mathrm{C}$ for 15 min then quickly cooled the reaction tubes with an ice bath. After that the mixtures were centrifuged at $10000 \mathrm{~g}$ for $15 \mathrm{~min}$. The absorbance of the supernatant was determined at $600 \mathrm{~nm}, 532 \mathrm{~nm}, 450 \mathrm{~nm}$ by spectrophotometer. Lipid peroxidation was expressed as the MDA content in $\mathrm{nM}$ per $\mathrm{g}$ of fresh weight (FW).

\subsection{Measurement of free proline}

Free proline was extracted and its concentration was measured by using the method of Bates et al. (1973). Leaf samples $(0.5 \mathrm{~g})$ were homogenized with $5 \mathrm{ml} 3 \%$ sulfosalicylic acid and then the homogenate was centrifuged at $3000 \mathrm{~g}$ for $10 \mathrm{~min}$. After that, the supernatant was heated $\left(80^{\circ} \mathrm{C}\right)$ for 1 hour and then the absorbance of the supernatant was determined at $520 \mathrm{~nm}$.

\subsection{Measurement of soluble protein}

Soluble protein was extracted and its concentration was measured by using the method of Coomassie Brilliant Blue Stain Method. $0.5 \mathrm{~g}$ of leaf samples were homogenized in $6 \mathrm{ml}$ of $50 \mathrm{mM}$ potassium phosphate buffer (pH7.8). Then the homogenate was centrifuged at $4000 \mathrm{~g}$ for $10 \mathrm{~min}$. To each $200 \mathrm{ul}$ of the supernatant, $3 \mathrm{ml}$ of Coomassie Brilliant Blue G-250 was added, after mixed and placed two minutes, the absorbance of the liquid mixture was determined at $595 \mathrm{~nm}$. The standard curve was made by bovine serum albumin.

\subsection{Measurement of non-protein thiol (NPT)}

Soluble protein was extracted and its concentration was measured by using the method of De Vos (1992). 0.2g fresh leaf samples were homogenized with $3 \mathrm{ml} 5 \%$ pre-cold sulfosalicylic acid $(6.3 \mathrm{mmol} \cdot \mathrm{L}-1 \mathrm{DTPA}, \mathrm{pH}<1)$ and then the homogenate was centrifuged at $10000 \mathrm{~g}$ for $10 \mathrm{~min}$ at $4^{\circ} \mathrm{C}$. Then $900 \mathrm{ul}$ of the supernatant was added into $41.89 \mathrm{ml}$ of $0.5 \mathrm{M} \mathrm{K} 2 \mathrm{HPO}$. After homogeneous mixed, $10 \mathrm{mM}$ DTNB $75 \mathrm{ul}(0.143 \mathrm{~mol} \cdot \mathrm{L}-1 \mathrm{~K} 2 \mathrm{HPO}, 6.3$ mmol-L-1DTPA, pH7.5) was added in and keep warm at $30^{\circ} \mathrm{C}$ for $5 \mathrm{~min}$. The absorbance of the liquid mixture was determined at $412 \mathrm{~nm}$.

\subsection{Statistical Analysis}

All data presented were means \pm standard value and the measurements were done with three replicates for statistical validity. One-way analysis of variance (ANOVA) was performed to check the variability of data and validity of the results. The data were analyzed with the software Statistical Package for the Social Sciences (SPSS, Chicago, IL, USA) version 13.0 and the results were considered significant if $\mathrm{P}<0.05$.

\section{Results}

\subsection{Growth}

The growth of height and DBH of P.yunnanensis for 40 days exposure to treatments were showed in Fig. 1. It showed that under the same $\mathrm{N}$ treatment, different concentrations of $\mathrm{Cd}$ stress on P.yunnanensis resulted in a significant inhibition on the growth of both height and $\mathrm{DBH}$, and this inhibition expressed more significantly with the increasing Cd concentrations. In addition, under the same Cd treatment, the height and DBH growth shows a dramatically increase along with the concentration of $\mathrm{N}$ increased. Results of univariate analysis (Table 1) indicated that $\mathrm{Cd}$ and $\mathrm{N}$ treatment both have extremely significant influence on the height and $\mathrm{DBH}$ growth of P.yunnanensis $(\mathrm{P}<0.01)$ and the interaction effect of $\mathrm{Cd}$ and $\mathrm{N}$ is significant $(\mathrm{P}<0.05)$. The results of multiple comparison(Table 2)shows that under the same $\mathrm{Cd}$ treatment, the increased concentration of $\mathrm{N}$ can significantly improve plants growth and the higher concentration of $\mathrm{N}(40 \mathrm{mg} / \mathrm{kg})$ plays more significant effect compared to the lower concentration of $\mathrm{N}(20 \mathrm{mg} / \mathrm{kg})$ which indicated the difference between different $\mathrm{N}$ level is significant $(\mathrm{P}<0.05)$.

\subsection{The concentrations of chlorophyll}

Chlorophyll is the main pigment which can help plants to photosynthesize. When plants exposure to stress, their photosynthesis will be inhibited and the concentrations of chlorophyll can directly indicate the extent of stress-induced damage in plants. The concentrations of chlorophyll in the leaves of P.yunnanensis for 40 days' exposure were showed in Fig. 2. All Cd treatments indicated a significant decrease in chlorophyll contents. It is obvious that under the same $\mathrm{N}$ level, the concentrations of chlorophyll in the leaves treated with $\mathrm{Cd}$ significantly decreased compared with that of control which indicated that $\mathrm{Cd}$ treatment had significant effect on the synthesis of chlorophyll and the inhibition effect was more significant along with the increased $\mathrm{Cd}$ level. On the other 
hand, the $\mathrm{N}$ treatment represented a significant improvement on the chlorophyll contents. The concentrations of chlorophyll witnessed a gradual rise along with the increased $\mathrm{N}$ level under the same concentration of $\mathrm{Cd}$ stress. According to the multiple comparison (Table 3), $\mathrm{Cd}$ and $\mathrm{N}$ treatment both had extremely significant influence on the chlorophyll content of P.yunnanensis $(\mathrm{P}<0.01)$ and the interaction effect of $\mathrm{Cd}$ and $\mathrm{N}$ was significant $(\mathrm{P}<0.05)$. According to the results of multiple comparison (Table 4), we can see clearly that under the same level of Cd stress, the concentrations of chlorophyll showed a positive correlation to that of $\mathrm{N}$ level and the higher concentration of $\mathrm{N}(40 \mathrm{mg} / \mathrm{kg})$ played more significant effect compared to the lower concentration of $\mathrm{N}$ $(20 \mathrm{mg} / \mathrm{kg})(\mathrm{P}<0.05)$, which indicated nitrogen can effectively alleviated Cd-induced inhabitation on chlorophyll synthesize.

\subsection{The activities of antioxidant enzymes}

Enzymatic antioxidant system is one of the protective mechanisms including SOD, POD, CAT and APX which can eliminate active oxygen species (AOS) in plants cell and alleviate stress-induced oxidative damage (Beak and Skinner, 2003). The activities of 4 antioxidant enzymes in the leaves of P.yunnanensis for 40 days exposure were showed in Fig. 3.

According to Fig .3a, it is shown that under the same concentration of $\mathrm{N}$ treatment, $\mathrm{Cd}$ stress induced a significant increase in SOD compared with control, which indicated that P.yunnanensis has a certain degree of resistance to Cd stress. Even when the Cd stress level reached at $2 \mathrm{mg} / \mathrm{kg}$, the stress didn't exceed the maximum resistance of plants. Additional, SOD activities represented a significant increase with the increasing $\mathrm{N}$ concentration under the same $\mathrm{Cd}$ level. From the results of multiple comparison (Table 5), it is indicated that $\mathrm{Cd}$ and $\mathrm{N}$ treatment both had significant influence on SOD activities $(\mathrm{P}<0.05)$. Furthermore, the concentrations of $\mathrm{N}$ were positively correlated to the activities of SOD (Table 6) and there also was significant difference of effects between higher $\mathrm{N}(40 \mathrm{mg} / \mathrm{kg})$ and lower $\mathrm{N}(20 \mathrm{mg} / \mathrm{kg})$.

POD activities were significant influenced by the interaction of $\mathrm{Cd}$ and $\mathrm{N}$ treatment. According to the Fig .3b, it is shown that under the same $\mathrm{N}$ level the POD activities gradually increased compared to that of control. On the contrary, at the same Cd treatment, POD activities witnessed a significant decrease along with the increased $\mathrm{N}$ level. From the results of multiple comparison (Table 5), both $\mathrm{Cd}$ and $\mathrm{N}$ treatment had significant influence on POD activities $(\mathrm{P}<0.05)$. Furthermore, the concentrations of $\mathrm{N}$ was positively correlated to the activities of SOD (Table 6) and the difference between different $\mathrm{N}$ level was significant $(\mathrm{P}<0.05)$.

For the CAT activities, there was a significant difference induced by different $\mathrm{Cd}$ treatment under the same $\mathrm{N}$ level $(\mathrm{P}<0.05)$. The activities witnessed a significant growth followed by a decline (Fig . $3 \mathrm{c}$ ) which indicated that with the increasing concentration of Cd stress, plants generated more CAT to eliminate active oxygen. However, when the $\mathrm{Cd}$ stress reached to a certain degree, CAT activities were inhibited. Additional, there was no significant difference among three $\mathrm{N}$ concentrations under the same $\mathrm{Cd}$ level (Table 5).

Both $\mathrm{Cd}$ and $\mathrm{N}$ treatment have significant influence on APX activities $(\mathrm{P}<0.05)$. According to Fig .3d, the APX activities showed a gradual rise with the increasing concentrations of $\mathrm{Cd}$ treatments under the same $\mathrm{N}$ level, which indicated that $\mathrm{Cd}$ treatment had significant effect on the APX activities. On the contrary, at the same Cd treatment, APX activities witnessed a slight decrease along with the increased $\mathrm{N}$ level. Although the concentrations of $\mathrm{N}$ were positively correlated to the activities of APX (Table 6) and N treatment could largely decreased APX activities, there were no significant difference of effects between higher $N(40 \mathrm{mg} / \mathrm{kg})$ and lower $\mathrm{N}(20 \mathrm{mg} / \mathrm{kg})$.

\subsection{The concentrations of MDA and free proline}

Malondialdehyde (MDA) is the main product of membrane lipid peroxidation which can indicate the extent of stress-induced damage in plants. The results in Fig. 4a showed that the MDA concentration in the leaves of P.yunnanensis is extremely increased under the Cd treatment compared with that of control, which suggested that the $\mathrm{Cd}$ treatments had a significant positive correlation to the MDA accumulation $(\mathrm{P}<0.01)$. On the contrary, under the same $\mathrm{Cd}$ level, the MDA content witnessed a significant decrease with the increasing concentration of $\mathrm{N}$ and the difference between different $\mathrm{N}$ level was significant(Table 8), which indicated $\mathrm{N}$ treatment can significant alleviated the lipid peroxidation in P.yunnanensis $(\mathrm{P}<0.01)$.

Free proline plays an important role in osmoregulation and its accumulation was considered significant for the adaptation to stress in plants (Tang, 1984). According to Table 7, the free proline concentrations in leaves of P.yunnanensis showed a significant difference under $\mathrm{Cd}$ stress $(\mathrm{P}<0.01)$. With the increasing $\mathrm{Cd}$ level, free proline content had a rapid rise followed by a slowly increase, which indicated that $\mathrm{Cd}$ stress improved the accumulation of free proline and played a protective role in P.yunnanensis. However, when the Cd level reached to a certain degree, the synthesis of proline was inhibited and influenced by the increased of proline (Fig. 4b). 
Additional, $\mathrm{N}$ treatment had no significant influenced on the concentration of free proline under the same $\mathrm{Cd}$ level and there was also no significant difference among three $\mathrm{N}$ concentrations (Table 8) which indicated that the concentrations of free proline were only affected by $\mathrm{Cd}$ stress.

\subsection{The concentrations of soluble protein and non-protein thiol (NPT)}

Soluble protein is an osmotic regulator in plant which can regulate plant cell osmosis under different stress. The accumulation of soluble protein can reduce the osmotic pressure of solute in cell and balance the inside and outside perviousness of protoplast, which play an important role in plant self-defence mechanism. The results in Fig. 5a showed that under the same concentration of $\mathrm{N}$ treatment, the soluble protein content witnessed a slight increase and followed by a sharp decline, which indicated that lower $\mathrm{Cd}(2 \mathrm{mg} / \mathrm{kg})$ stress induced the synthesis of new protein and the higher $\mathrm{Cd}(4 \mathrm{mg} / \mathrm{kg})$ might inhibited this synthesis, resulting in a part of protein decomposed in plants. Meanwhile, under the same Cd level, the soluble protein content showed a significant increase with the increasing concentration of $\mathrm{N}$. According to the multiple comparison (Table 9), $\mathrm{Cd}$ and $\mathrm{N}$ treatment both had extremely significant influence on the soluble protein content of P.yunnanensis $(\mathrm{P}<0.01)$. According to the results of multiple comparison (Table 10), we can see clearly that under the same level of Cd stress, the concentrations of soluble protein showed a positive correlation to that of $\mathrm{N}$ level and the difference between different $\mathrm{N}$ level was significant $(\mathrm{P}<0.05)$, which indicated $\mathrm{N}$ treatment can significant induce the synthesis of protein in P.yunnanensis.

Non-protein thiol (NPT) including PCs, GSH, $\gamma$-EC and cysteine, having a close relationship with heavy metals stress and the metabolism of sulfur in plants. When sulfur is sufficient, plants can synthetize a large amount of NPT to combine with heavy metals, which can be helpful to decrease the over-accumulation of heavy metals in plants. According to Fig. 5b, the NPT content in leaves of P.yunnanensis showed a significant increase with the increasing concentration of $\mathrm{Cd}$, which indicated that $\mathrm{Cd}$ stress could obviously induced the content of NPT in plants $(\mathrm{P}<0.01)$. Additional, $\mathrm{N}$ treatment had no significant influenced on the NPT content under the same $\mathrm{Cd}$ level and there was also no significant difference among three $\mathrm{N}$ concentrations (Table 10) which indicated that the NPT content was only affected by Cd stress.

\section{Conclusions}

$\mathrm{Cd}$ contaminated has detrimental influence on plants growth and development. Over-accumulation of Cd concentration in plants shows differential symptoms of toxicity including the growth inhibition, leaves chlorosis and biomass decrease. Our results showed that $\mathrm{Cd}$ stress obviously inhibited the growth of P.yunnanensis, slowed down the synthesis process of chlorophyll which decreased its concentration in plants.

Additional, over-accumulated $\mathrm{Cd}$ can also influence the physiological and biochemical process of plants. Specifically, Cd injury to plants is mainly because of altered oxidant levels, which causing the occurrence of oxidative stress due to accumulation of active oxygen species (AOS), including superoxide radical $\left(\mathrm{O}^{2-}\right)$, hydroxyl radical $\left(\mathrm{OH}^{-}\right)$and hydrogen peroxide $\left(\mathrm{H}_{2} \mathrm{O}_{2}\right)$. In normal circumstances, the speeds of generation and elimination of AOS is balanced. However, when plants expose to $\mathrm{Cd}$ stress, plants generate more AOS than elimination. As soon as the balance is broken, the over-accumulation of AOS in plants lead to significant damage to membrane system of plants which can induce lipid peroxidation reaction as well as increase permeability and conductivity (Gallego et al., 1996; Chaoui et al., 1997). The concentration of malondialdehyde (MDA), which is a general indicator of lipid peroxidation, can demonstrate the extent of oxidative stress in plants (Chaouiet al., 1997). On the contrary, plants cells have their own self-defense mechanisms against AOS. One of the protective mechanisms is the enzymatic antioxidant system, which involves the sequential and simultaneous action of a number of enzymes such as SOD, POD, CAT, APX (Bowler et al., 1992), to eliminate the over-accumulated AOS in plants. The other protective mechanism of plants is to generate amount of free proline to regulate the osmotic pressure in cell which can prevent cell from dehydration. Our results showed that under Cd stress, MDA concentration was largely increased with the increasing $\mathrm{Cd}$ level which suggested that under the increasing concentration of $\mathrm{Cd}$ stress, the AOS was over-accumulated in plants which resulted in dramatical lipid peroxidation reaction. Meanwhile, the self-defense mechanism of P.yunnanensis was intrigued and plants enhanced the activities of their antioxidant enzymes system (including SOD, POD, CAT and APX) to eliminate the over-accumulated AOS and prevent them from oxidative damage. However, with the increasing concentration of Cd stress, except for the CAT activity, the other activities of antioxidant enzymes weren't inhibited by $\mathrm{Cd}$ stress even under the higher Cd concentration $(4 \mathrm{mg} / \mathrm{kg})$ which indicated that P.yunnanensis had a certain degree of resistance to $\mathrm{Cd}$ stress and the concentration of $\mathrm{Cd}$ treatment did not exceed its maximum capacity of resistance. Thus the oxidative stress caused by $\mathrm{Cd}$ addition was moderate which allowing the plants to adapt it actively by increasing their own antioxidant enzymes activity. Meanwhile, increased activities of these antioxidant enzymes in plants following the increasing $\mathrm{Cd}$ treatment in this study demonstrated that these 
enzymes acted together to alleviate the impact of Cd stress. Besides, the concentration of free proine and NPT showed a positive correlation with the increased $\mathrm{Cd}$ level which indicated that P.yunnanensis could generated amount of free proline and NPT to prevent cell from dehydration under Cd stress. Meanwhile, lower Cd (2 $\mathrm{mg} / \mathrm{kg}$ ) stress could enhance the synthesis of soluble protein in plants and the higher $\mathrm{Cd}(4 \mathrm{mg} / \mathrm{kg})$ might inhibit this synthesis. Lastly, it is worth noting that the influenced of Cd stress on plants had significant difference among those three $\mathrm{Cd}$ concentrations.

Nitrogen is one of the essential nutrient elements. The deficiency of nitrogen will lead to metabolic disturbance in plants, thus causing the decrease of plants growth and productivities. With pollution of heavy metals being serious day by day, the heavy metals stress may become the main reason of the deficiency or inefficiency of nutrient element. Meanwhile, supplement of nitrogen for plants can obviously alleviate heavy metal-reduced damage (An et al., 2002). Williams (1967) suggested that adding nitrogen to soil, nitrification will occur and obviously decreased the $\mathrm{pH}$ of soil, thus significant increasing the solubility of heavy metals in soil which decrease the adsorption amount of heavy metals.

In this study, the researchers discovered that nitrogen could effectively alleviated Cd-induced damage in $P$. yunnanensis, and there was a significant difference of effects on plants between lower $\mathrm{N}$ concentration (20 $\mathrm{mg} / \mathrm{kg}$ ) and higher $\mathrm{N}$ concentration $(40 \mathrm{mg} / \mathrm{kg}$ ). Supplement of high-concentration nitrogen to P. yunnanensis under $\mathrm{Cd}$ stress obviously enhanced plants growth, promoted the synthesis of chlorophyll, free proline, soluble protein and NPT, as well as the activities of antioxidant enzymes which partially alleviated the accumulation of AOS associated with $\mathrm{Cd}$ exposure. Our results indicated that the higher $\mathrm{N}$ supplement had more significant effect of alleviation on Cd-induced damage than that of lower $\mathrm{N}$ treatment in Populus yunnanensis.

\section{Acknowledgement}

The research was supported by the Key Project of Crop Breeding of Sichuan Province (No.2006Y2GG-10) and the Open-End Fund of National Engineering Laboratory of Forest Tree Breeding of Beijing Forestry University (No.FOP 2010-7).

\section{References}

Aebi, H. (1984). Catalase in vitro. Method of Enzymology, 105, 121-126. http://dx.doi.org/10.1016/S0076-6879(84)05016-3

Bates LS, Waldren RP, Teare ID. (1973). Rapid determination of free proline for water stress studies. Plants Soil, 39:205-207. http://dx.doi.org/10.1007/BF00018060

B. Chakravarty, S. Srivastava. (1992). Toxicity of some heavy metals invivo and in vitro in helianthus annuus, Mutat. Res, 283, 287-294. http://dx.doi.org/10.1016/0165-7992(92)90061-L

Bowler C, van Montagu M, \& Inze D. (1992). Superoxide dismutase and stress tolerance. Annu. Rev. Plants Physiol. Mol. Biol., 43, 83-116. http://dx.doi.org/10.1146/annurev.pp.43.060192.000503

Beak, K.H., \& Skinner, D.Z. (2003). Alteration of antioxidant enzyme gene expression during cold acclimation of near-isogenic wheat lines. Plants Science, 165, 1221-1227. http://dx.doi.org/10.1016/S0168-9452(03)00329-7

Chaoui A, Mazhoudi S, Ghorbal M H, \& Ferjani E L. (1997). Cd and zinc induction of lipid peroxidation and effects on antioxidant enzyme activities in bean (Phaseolus ulgaris L.). Plants Sci., 127, 139-147. http://dx.doi.org/10.1016/S0168-9452(97)00115-5

De Vos C H R, Vonk M J, Vooijs R, et al. (1992). Glutathione depletion due to copper-induced phytochelatin synthesis causes oxidative stress in silene cucubalus. Plant Physiology, 98(3):853-858. http://dx.doi.org/10.1104/pp.98.3.853

Esfandiari, E. A., Shakiba, M. R., Mahboob, S. A., Alyari, H., \& Toorchi, M. (2007). Water stress, antioxidant enzyme activity and lipid peroxidation in wheat seedling. Journal of Food, Agriculture \& Environment, 5, 48-53.

Gallego S M, Benavy des M P, \& Tomaro M. (1996). Effect of heavy metal ion excess on sunflower leaves: evidence for involvement of oxidative stress. Plants Sci., 121, 151-159. http://dx.doi.org/10.1016/S0168-9452(96)04528-1

Guo TR, Zhang GP, Zhou MX, Wu FB, \& Chen JX. (2004). Effects of aluminum and Cd toxicity on growth and antioxidant enzyme activities of two barley genotypes with different Al resistance. Plants Soil, 258:241-248. http://dx.doi.org/10.1023/B:PLSO.0000016554.87519.d6

Lichtenthaler HK. (1987). Chlorophylls and carotenoids: pigments of photosynthetic membranes. In: Packer L, Douce R (eds). Methods in enzymology. Academic Press, New York, pp 350-382. 
Li JG, Jin SL, Chen YQ, Lin GL, Han XR, Li TQ, Yang XE, \& Zhu E. (2007). Effects of nitrogen fertilizer on the root morphology and $\mathrm{Cd}$ accumulation in low $\mathrm{Cd}$ treatment sedum alfredii Hance. Chinese Agricultural Science Bulletin, Vol. 23, 260-265.

Muhammad Jaffar Hassan, Feng Wang, Shaukat Ali, \& Guoping Zhang. (2005). Toxic effect of Cd on rice as affected by nitrogen fertilizer form. Plants \& Soil, 277:359-365. http://dx.doi.org/10.1007/s11104-005-8160-6

P. Das, S. Samantaray, G.R. Rout. (1997). Studies on Cd toxicity in plantss: a review, Environment Pollution, 98, 29-36. http://dx.doi.org/10.1016/S0269-7491(97)00110-3

Stewart, R. R. C., \& Bewley, J. D. (1980). Lipid peroxidation associated aging of soybean axes. Plants Physiology, 65, 245-248. http://dx.doi.org/10.1104/pp.65.2.245

Sairam, R. K., Rao, K. V., \& Srivastava, G. C. (2002). Differential response of wheat genotypes to long term salinity stress in relation to oxidative stress, antioxidant activity and osmolyte concentration. Plants Science, 163, 1037-1046. http://dx.doi.org/10.1016/S0168-9452(02)00278-9

Tang ZC. (1984). The accumulation of free proline and its possible significance in plants under stress. Plants Physiology Communications, 1984(1):15-21.

Williams C H, Singh R N, Vlamis A H. (1967). Metals in Sludge—amended soils: a nine-year study. Soil Science, 2, 86-93.

Wang ZA, Wang XC, Shi WM et al. (2002). The physiological effects of interaction of heavy metal and nutrient elements on plants. Soil \& Enviroment, 11(4), 392-396.

Yoshimura, K., Yabute, Y., Ishikawa, T., \& Shigeoka, S. (2000). Expression of spinach ascorbate peroxidase isoenzymes in response to oxidative stresses. Plants Physiology, 123, 223-233. http://dx.doi.org/10.1104/pp.123.1.223

Zhang WQ. (2008). Variation of some physiological process and biomass of kandelia candel under stress of $N$ and $C d$. The academic dissertation of Fujian Agriculture and Forestry University.

Table 1. Analysis of variance significance for the interaction effects of $\mathrm{Cd}$ and $\mathrm{N}$ on height and $\mathrm{DBH}$ growth in P.yunnanensis

\begin{tabular}{|c|c|c|c|c|}
\hline \multirow{2}{*}{ Univariate } & \multicolumn{2}{|c|}{ Height } & \multicolumn{2}{c|}{ DBH } \\
\cline { 2 - 5 } & $\mathrm{F}$ & $\mathrm{p}$ & $\mathrm{F}$ & $\mathrm{p}$ \\
\hline $\mathrm{Cd}$ & 72.834 & $0.0007<0.01$ & 31.273 & $0.0036<0.01$ \\
\hline $\mathrm{N}$ & 97.375 & $0.0004<0.01$ & 19.483 & $0.0087<0.01$ \\
\hline
\end{tabular}

Table 2. Multiple comparison of height and DBH growth on $\mathrm{N}$ treatment under different $\mathrm{Cd}$ concentrations in P.yunnanensis. Different letters show significant difference

\begin{tabular}{|c|c|c|c|}
\hline \multicolumn{2}{|c|}{ Treatment $(\mathrm{mg} / \mathrm{kg})$} & \multicolumn{2}{c|}{ Average growth $(\mathrm{cm})$} \\
\hline $\mathrm{Cd}$ & $\mathrm{N}$ & Height & $\mathrm{DBH}$ \\
\hline \multirow{3}{*}{0} & 0 & $4.33 \mathrm{~b}$ & $0.58 \mathrm{~b}$ \\
\cline { 2 - 4 } & 20 & $4.83 \mathrm{~b}$ & $0.64 \mathrm{ab}$ \\
\cline { 2 - 4 } & 40 & $6.17 \mathrm{a}$ & $0.77 \mathrm{a}$ \\
\hline \multirow{3}{*}{2} & 0 & $3.17 \mathrm{~b}$ & $0.48 \mathrm{~b}$ \\
\cline { 2 - 4 } & 20 & $3.9 \mathrm{~b}$ & $0.57 \mathrm{ab}$ \\
\hline \multirow{4}{*}{4} & 40 & $5.5 \mathrm{a}$ & $0.6 \mathrm{a}$ \\
\cline { 2 - 4 } & 0 & $2.67 \mathrm{~b}$ & $0.43 \mathrm{~b}$ \\
\cline { 2 - 4 } & 20 & $3.15 \mathrm{~b}$ & $0.47 \mathrm{ab}$ \\
\hline
\end{tabular}

Table 3. Analysis of variance significance for the interaction effects of $\mathrm{Cd}$ and $\mathrm{N}$ on chlorophyll content in P.yunnanensis

\begin{tabular}{|c|c|c|}
\hline \multirow{2}{*}{ Univariate } & \multicolumn{2}{|c|}{ chlorophyll content } \\
\cline { 2 - 3 } & $\mathrm{F}$ & $\mathrm{p}$ \\
\hline $\mathrm{Cd}$ & 334.09 & $0.0001<0.01$ \\
\hline $\mathrm{N}$ & 87.756 & $0.0005<0.01$ \\
\hline
\end{tabular}


Table 4. Multiple comparison of chlorophyll content on $\mathrm{N}$ treatment under different Cd concentrations in P.yunnanensis. Different letters show significant difference

\begin{tabular}{|c|c|c|}
\hline \multicolumn{2}{|c|}{ Treatment $(\mathrm{mg} / \mathrm{kg})$} & \multirow{2}{*}{ chlorophyll content $\left(\mathrm{mg} \cdot \mathrm{g}^{-1} \mathrm{FW}\right)$} \\
\hline \multirow{4}{*}{0} & $\mathrm{~N}$ & $3.085 \mathrm{~b}$ \\
\cline { 2 - 3 } & 0 & $3.301 \mathrm{~b}$ \\
\cline { 2 - 3 } & 20 & $3.865 \mathrm{a}$ \\
\hline \multirow{3}{*}{2} & 40 & $1.757 \mathrm{~b}$ \\
\cline { 2 - 3 } & 0 & $1.988 \mathrm{~b}$ \\
\cline { 2 - 3 } & 20 & $2.557 \mathrm{a}$ \\
\hline \multirow{3}{*}{4} & 0 & $1.25 \mathrm{~b}$ \\
\cline { 2 - 3 } & 20 & $1.66 \mathrm{~b}$ \\
\cline { 2 - 3 } & 40 & $2.324 \mathrm{a}$ \\
\hline
\end{tabular}

Table 5. Analysis of variance significance for the interaction effects of $\mathrm{Cd}$ and $\mathrm{N}$ on antioxidant enzymes activities in P.yunnanensis

\begin{tabular}{|c|c|c|c|c|c|c|c|c|}
\hline \multirow{2}{*}{ Univariate } & \multicolumn{2}{|c|}{ SOD } & \multicolumn{2}{c|}{ POD } & \multicolumn{2}{c|}{ CAT } & \multicolumn{2}{c|}{ APX } \\
\cline { 2 - 10 } & $\mathrm{F}$ & $\mathrm{P}$ & $\mathrm{F}$ & $\mathrm{p}$ & $\mathrm{F}$ & $\mathrm{p}$ & $\mathrm{F}$ & $\mathrm{p}$ \\
\hline $\mathrm{Cd}$ & 15.162 & $0.0136<0.05$ & 48.581 & $0.0016<0.05$ & 27.129 & $0.0047<0.05$ & 13.393 & $0.0169<0.05$ \\
\hline $\mathrm{N}$ & 11.407 & $0.0429<0.05$ & 28.399 & $0.0043<0.05$ & 2.777 & $0.1753>0.05$ & 16.233 & $0.012<0.05$ \\
\hline
\end{tabular}

Table 6. Multiple comparison of antioxidant enzymes activities on $\mathrm{N}$ treatment under different Cd concentrations in P.yunnanensis. Different letters show significant difference

\begin{tabular}{|c|c|c|c|c|c|}
\hline \multicolumn{4}{|c|}{ Treatment(mg/kg) } & \multicolumn{4}{|c|}{ enzymes activities $\left(\mathrm{U} \cdot \mathrm{g}^{-1} \cdot \mathrm{min}^{-1} \mathrm{FW}\right)$} \\
\hline $\mathrm{Cd}$ & $\mathrm{N}$ & SOD & POD & CAT & APX \\
\hline \multirow{4}{*}{0} & 0 & $517 \mathrm{~b}$ & $188 \mathrm{a}$ & $8.83 \mathrm{a}$ & $5.26 \mathrm{a}$ \\
\cline { 2 - 6 } & 20 & $521 \mathrm{ab}$ & $169 \mathrm{~b}$ & $9.08 \mathrm{a}$ & $4.89 \mathrm{~b}$ \\
\cline { 2 - 6 } & 40 & $523 \mathrm{a}$ & $138 \mathrm{c}$ & $9.00 \mathrm{a}$ & $4.77 \mathrm{~b}$ \\
\hline \multirow{4}{*}{2} & 0 & $528 \mathrm{~b}$ & $278 \mathrm{a}$ & $12.64 \mathrm{a}$ & $5.51 \mathrm{a}$ \\
\cline { 2 - 6 } & 20 & $532 \mathrm{ab}$ & $239 \mathrm{~b}$ & $12.96 \mathrm{a}$ & $5.32 \mathrm{~b}$ \\
\cline { 2 - 6 } & 40 & $549 \mathrm{a}$ & $179 \mathrm{c}$ & $15.40 \mathrm{a}$ & $5.05 \mathrm{~b}$ \\
\hline \multirow{4}{*}{4} & 0 & $540 \mathrm{~b}$ & $308 \mathrm{a}$ & $11.04 \mathrm{a}$ & $5.95 \mathrm{a}$ \\
\cline { 2 - 6 } & 20 & $553 \mathrm{ab}$ & $275 \mathrm{~b}$ & $12.24 \mathrm{a}$ & $5.28 \mathrm{~b}$ \\
\cline { 2 - 6 } & 40 & $577 \mathrm{a}$ & $220 \mathrm{c}$ & $12.64 \mathrm{a}$ & $5.24 \mathrm{~b}$ \\
\hline
\end{tabular}

Table 7. Analysis of variance significance for the interaction effects of $\mathrm{Cd}$ and $\mathrm{N}$ on MDA and free proline content in P.yunnanensis

\begin{tabular}{|c|c|c|c|c|}
\hline \multirow{2}{*}{ Univariate } & \multicolumn{2}{|c|}{ MDA } & \multicolumn{2}{c|}{ Free proline } \\
\cline { 2 - 5 } & $\mathrm{F}$ & $\mathrm{p}$ & $\mathrm{F}$ & $\mathrm{p}$ \\
\hline $\mathrm{Cd}$ & 69.768 & $0.0008<0.01$ & 95.642 & $0.0004<0.01$ \\
\hline $\mathrm{N}$ & 61.172 & $0.001<0.01$ & 3.844 & $0.1171>0.05$ \\
\hline
\end{tabular}

Table 8. Multiple comparison of MDA and free proline content on $\mathrm{N}$ treatment under different Cd concentrations in P.yunnanensis. Different letters show significant difference

\begin{tabular}{|c|c|c|c|}
\hline \multicolumn{2}{|c|}{ Treatment $(\mathrm{mg} / \mathrm{kg})$} & \multirow{2}{*}{ MDA } & \multirow{2}{*}{ Free proline } \\
\hline $\mathrm{Cd}$ & $\mathrm{N}$ & $14.9 \mathrm{a}$ & $9.2 \mathrm{a}$ \\
\hline \multirow{3}{*}{0} & 0 & $13.1 \mathrm{~b}$ & $10.1 \mathrm{a}$ \\
\cline { 2 - 4 } & 20 & $10.2 \mathrm{c}$ & $9.6 \mathrm{a}$ \\
\cline { 2 - 4 } & 40 & $17.5 \mathrm{a}$ & $15.4 \mathrm{a}$ \\
\hline \multirow{3}{*}{2} & 0 & $16.6 \mathrm{~b}$ & $16.6 \mathrm{a}$ \\
\cline { 2 - 4 } & 20 & $12.4 \mathrm{c}$ & $17.5 \mathrm{a}$ \\
\cline { 2 - 4 } & 40 & $21.8 \mathrm{a}$ & $18.1 \mathrm{a}$ \\
\hline \multirow{3}{*}{4} & 0 & $19.3 \mathrm{~b}$ & $19.3 \mathrm{a}$ \\
\cline { 2 - 4 } & 20 & $15.1 \mathrm{c}$ & $21.8 \mathrm{a}$ \\
\cline { 2 - 4 } & 40 & & \\
\hline
\end{tabular}


Table 9. Analysis of variance significance for the interaction effects of $\mathrm{Cd}$ and $\mathrm{N}$ on soluble protein and NPT content in P.yunnanensis

\begin{tabular}{|c|c|c|c|c|}
\hline \multirow{2}{*}{ Univariate } & \multicolumn{2}{|c|}{ soluble protein } & \multicolumn{2}{c|}{ NPT } \\
\cline { 2 - 5 } & $\mathrm{F}$ & $\mathrm{p}$ & $\mathrm{F}$ & $\mathrm{p}$ \\
\hline $\mathrm{Cd}$ & 46.552 & $0.0017<0.01$ & 201.56 & $0.0001<0.01$ \\
\hline $\mathrm{N}$ & 36.385 & $0.0027<0.01$ & 2.754 & $0.177>0.05$ \\
\hline
\end{tabular}

Table 10. Multiple comparison of soluble protein and NPT content on $\mathrm{N}$ treatment under different Cd concentrations in P.yunnanensis. Different letters show significant difference

\begin{tabular}{|c|c|c|c|}
\hline \multicolumn{2}{|c|}{ Treatment $(\mathrm{mg} / \mathrm{kg})$} & \multirow{2}{*}{ soluble protein } & \multirow{2}{*}{ NPT } \\
\hline \multirow{3}{*}{0} & $\mathrm{~N}$ & $139 \mathrm{c}$ & $23.3 \mathrm{a}$ \\
\hline \multirow{3}{*}{2} & 0 & $152 \mathrm{~b}$ & $24.7 \mathrm{a}$ \\
\cline { 2 - 4 } & 20 & $160 \mathrm{a}$ & $24.9 \mathrm{a}$ \\
\cline { 2 - 4 } & 40 & $155 \mathrm{c}$ & $35.2 \mathrm{a}$ \\
\hline \multirow{3}{*}{4} & 0 & $165 \mathrm{~b}$ & $34.3 \mathrm{a}$ \\
\cline { 2 - 4 } & 20 & $178 \mathrm{a}$ & $36.1 \mathrm{a}$ \\
\hline \multirow{3}{*}{4} & 40 & $123 \mathrm{c}$ & $38.0 \mathrm{a}$ \\
\cline { 2 - 4 } & 0 & $134 \mathrm{~b}$ & $40.9 \mathrm{a}$ \\
\cline { 2 - 4 } & 20 & $155 \mathrm{a}$ & $41.1 \mathrm{a}$ \\
\hline
\end{tabular}
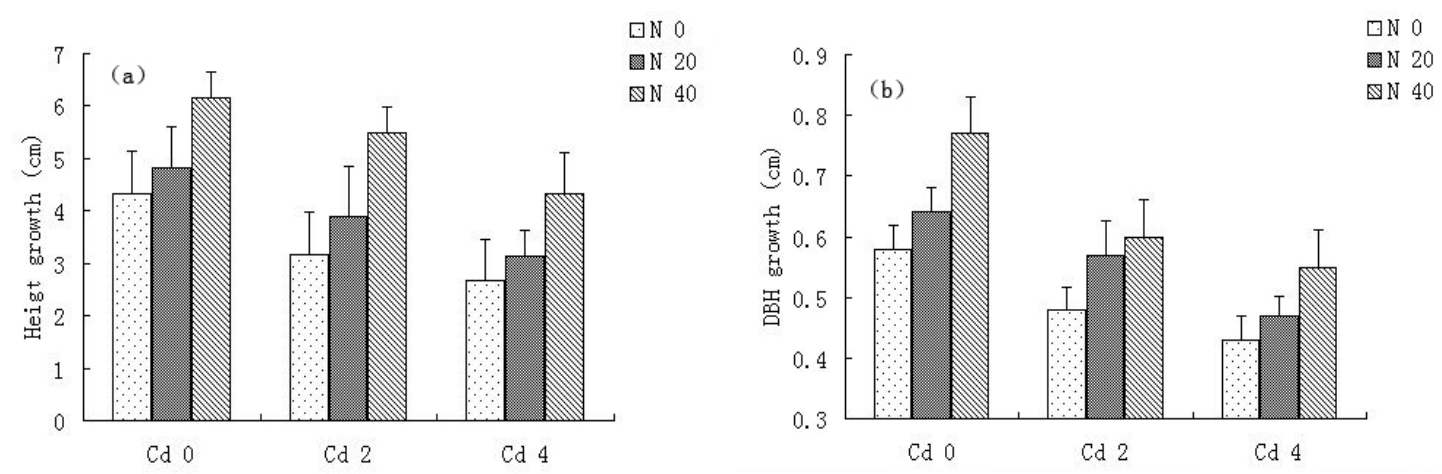

Figure 1. Interactive effects of $\mathrm{Cd}$ and $\mathrm{N}$ treatment on growth of height and DBH in P.yunnanensis, (a) Height growth, (b) DBH growth. Values are the means $\pm \mathrm{SE}$ of three replicate measurements

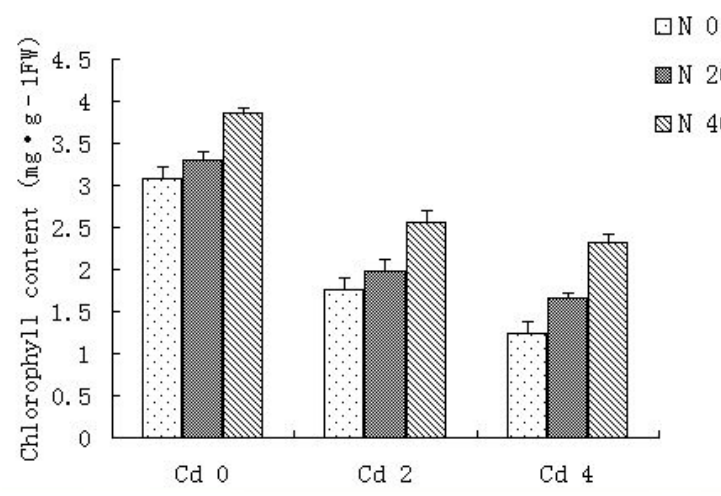

Figure 2. Interactive effects of $\mathrm{Cd}$ and $\mathrm{N}$ treatment on chlorophyll contents of P.yunnanensis. Values are the means \pm SE of three replicate measurements 

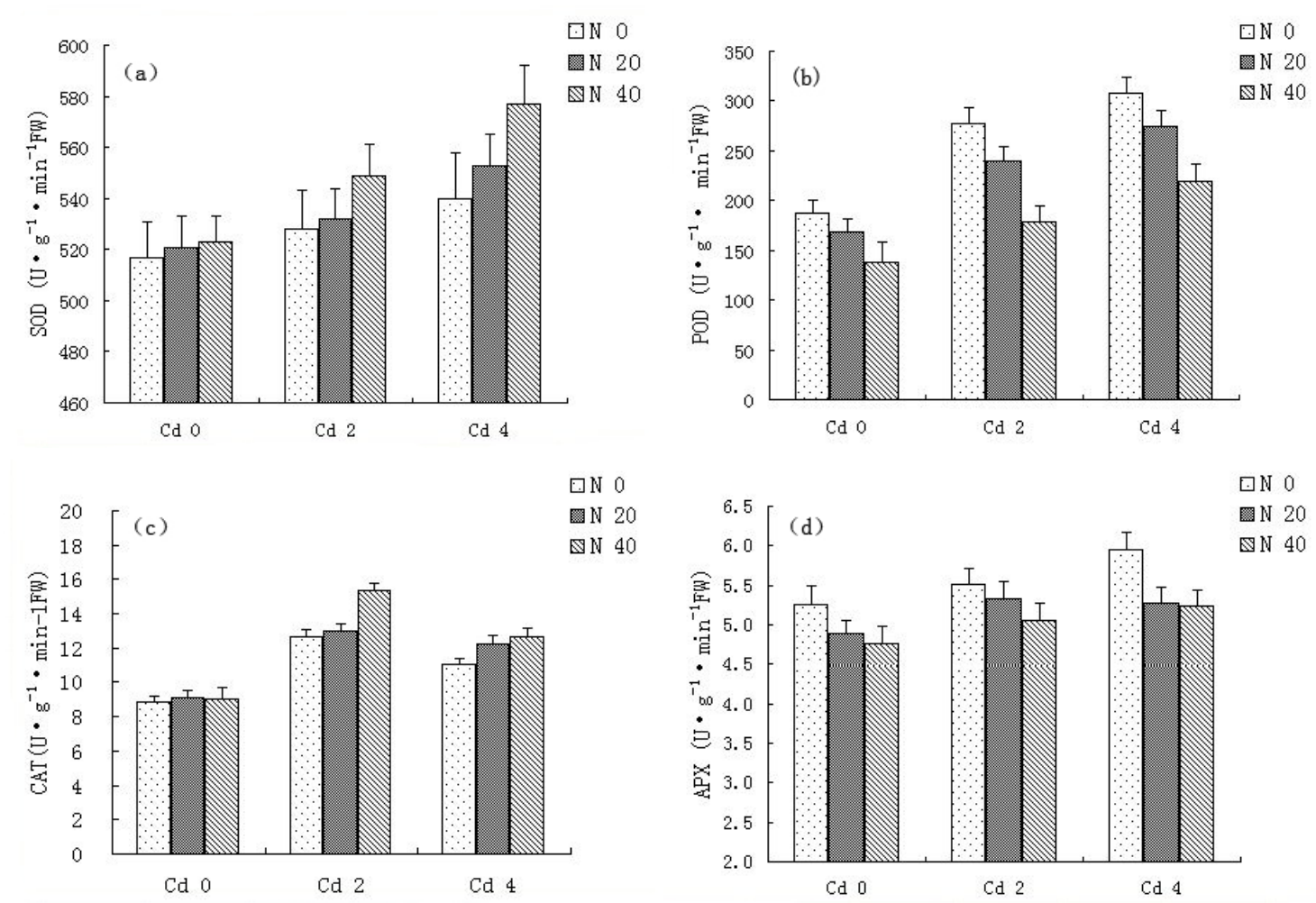

Figure 3. Interactive effect of $\mathrm{Cd}$ and $\mathrm{N}$ treatment on antioxidant enzymes activities in P.yunnanensis, (a) SOD activities, (b) POD activities, (c) CAT activities, (d) APX activities. Values are the means \pm SE of three replicate measurements
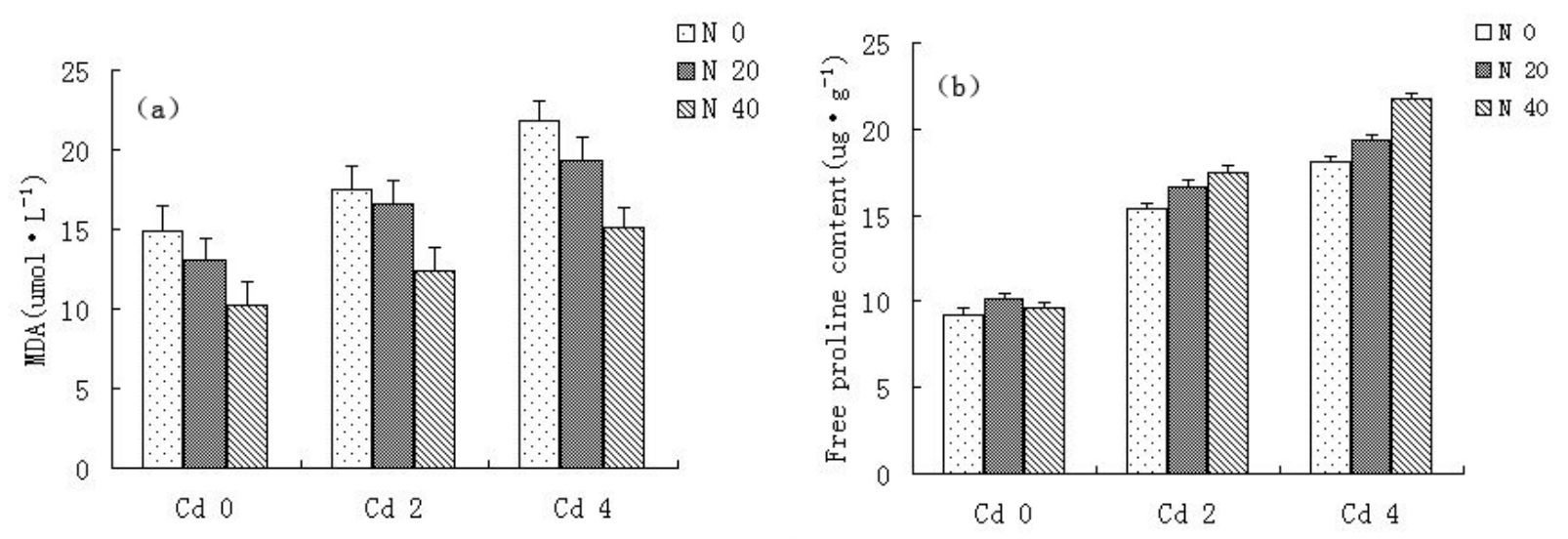

Figure 4. Interactive effect of $\mathrm{Cd}$ and $\mathrm{N}$ treatment on MDA and free proline content in P.yunnanensis, (a) MDA content, (b) Free proline content. Values are the means \pm SE of three replicate measurements

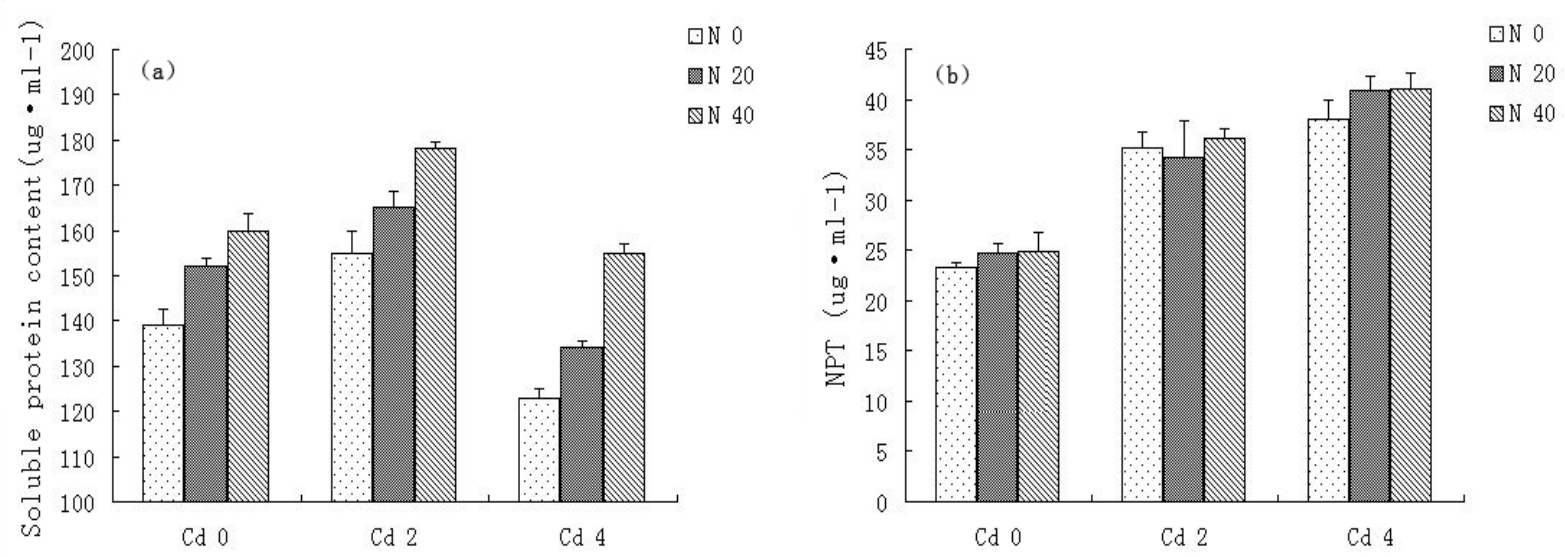

Figure 5. Interactive effect of Cd and N treatment on soluble protein and NPT content in P.yunnanensis, (a) soluble protein content, (b) NPT content. Values are the means \pm SE of three replicate measurements 